\title{
Bitter Melon (Momordica charantia L.) and Star fruit (Averrhoa bilimbi L.) on Proinflammatory Cytokines Produced by Hyperglycemic Mice Model
}

\author{
Bella Pradina Novinda Wardani, Sri Rahayu, Muhaimin Rifa'i* \\ Department of Biology, Faculty of Mathematics and Natural Sciences, University of Brawijaya, Malang, Indonesia
}

\begin{abstract}
Hyperglycemia is a condition of excessive blood glucose in blood plasma caused by damage to the pancreatic beta-cell structure that causes impaired insulin secretion. This study aimed to investigate the combination of Bitter Melon and Star Fruit ethanol extract (SBME) on pro-inflammatory cytokines production in hyperglycemic albino mice models. This study was treated in 25 female albino mice weighing 25-30 and 9 weeks old. STZ was given in a dose of $145 \mathrm{mg}^{\mathrm{kg}} \mathrm{kgW}^{-1} \mathrm{BW}$ intraperitoneally. Hyperglycemic mice were given orally with SBME ethanol extract at doses 10, 40, and $160 \mathrm{mg}^{\mathrm{kg}} \mathrm{kg}^{-1} \mathrm{BW}$ for two weeks. After treatment, pro-inflammatory molecules were analyzed by flow cytometry from the splenic cell. This study showed that SBME treatment can reduce the production of pro-inflammatory cytokines especially IL-1b, but increases IL-6 in hyperglycemic mice. After treatment with SBME at a dose of 40 , the IL-1b pro-inflammation molecule decreased significantly $(p>0,05)$. It reached a normal physiological level, but the dose has not been able to reduce the IL-6 pro-inflammation molecule significantly. The conclusion of this study was Bitter Melon and Star Fruit ethanol extract (SBME) with a treatment of $40 \mathrm{mg} \cdot \mathrm{kg}^{-1} \mathrm{BW}$ can suppress IL-1b pro-inflammatory cytokines in hyperglycemic mice models, but has not been able to reduce the expression of IL-6 pro-inflammatory cytokines. Suggesting this medicinal herb might be a useful strategy for future therapeutic interventions in degenerative diseases or diseases involving cell activation, but a study of doses is needed.
\end{abstract}

Keywords: Averrhoa bilimbi L., Hyperglycemia, Inflammation, Momordica charantia L.

\section{INTRODUCTION}

Hyperglycemia is a state of the body with high blood glucose levels. The hyperglycemic condition can trigger the appearance of various damages to the body's systems. The condition of hyperglycemia can occur due to several factors such as over nutrition, lack of exercise, stress, free radicals, increased ROS in the body, oxidative stress, and suffering from diabetes. Hyperglycemia is a typical criterion for people with diabetes, whether caused by decreased insulin secretion (Type 1 Diabetes/DMT1) or insulin resistance (Type 2 Diabetes/DMT2). Hyperglycemia, if left unchecked, can cause chronic diabetes to cause death [1].

Hyperglycemia is related to physiological conditions of the body, and one of them is due to immune system disorders. Hyperglycemia can affect the immune system because of increasing levels of pro-inflammatory cytokines IL-1b and IL6 in monocyte cells. IL-1b and IL- 6 are the central pro-inflammatory cytokines produced by macrophages [2]. Increased levels of IL-1b and IL6 are related to NF-KB activation. NF-KB is an essential regulator of gene expression in proinflammatory cytokines [3].

\footnotetext{
* Correspondence address:

Muhaimin Rifa'i

Email : rifa123@ub.ac.id

Address : Dept. Biology, University of Brawijaya, Veteran Malang, 65145
}

People with diabetes need therapies throughout their lives to reduce symptoms, prevent disease progression, and prevent the development of complications [4]. Various treatments, such as insulin therapy and diet, have been carried out. One alternative that can be used is herbal medicine. Many traditional medicinal plants have been proven to be used as antidiabetic, such as bitter melon and starfruit.

Bitter melon (Momordica charantia L.) was known to have antidiabetic activity $[5,6]$. Bitter melon contains several active compounds such as saponins, flavonoids, polyphenols, vitamin C, charantin, vicine, and polypeptide- $p$, which are considered as the main hypoglycemic compounds of bitter melon fruit [6]. Pare fruit contains an active compound that resembles a sulfonylurea (an antidiabetic drug), called momordicin, which can stimulate the $\beta$ cells of the pancreas to produce insulin [5].

Reactive Oxygen Species (ROS) will increase in the individual suffering from hyperglycemia and lead to oxidative stress [7]. However, an exogenous antioxidant from Starfruit (Averrhoa bilimbi L.) can overcome oxidative stress. Antioxidants can be obtained from Starfruit because of the content of active compounds such as flavonoids, saponins, and vitamin C [8]. That compounds are one of the natural ingredients that have antioxidant activity that can reduce inflammation. Therefore, this study was conducted to determine the effect of Bitter 
melon and star fruit extract on the proinflammation cytokine such as IL-1b and IL-6 in hyperglycemic Balb/c mice.

\section{MATERIAL AND METHOD STZ Induction}

The study was conducted using 25 female albino Balb/C mice aged nine weeks with a weight of $25 \mathrm{~g}$. The treatment consisted of five treatment groups and was repeated five times. Before treatment, the mice were acclimatized for ten days in the pathogen-free facility provided by the Biology Department, Brawijaya University. Mice were maintenance in $12 \mathrm{~h}$ dark/light with food and water added ad libitum. Hyperglycemia was induced by STZ in doses of $145 \mathrm{mg} . \mathrm{kg}^{-1} \mathrm{BW}$ intraperitoneally. The blood glucose level was tested using the Easy Touch glucometer strip. Mice were considered to have hyperglycemia when the fasting blood glucose level (FBG) > 200 $\mathrm{mg} \cdot \mathrm{dL}^{-1}$.

\section{Oral Administration of SBME}

The simplicia of Bitter melon and starfruit was obtained from Materia Medica (Batu, East Java). The extraction of bitter melon and star fruit simplicia with ethanol was processed using the maceration method with ethanol as a solvent. Soaking was done with $1 \mathrm{~L}$ of ethanol and stirred, then filtered after maceration for $1 \times 24$ hours, and replaced with a new ethanol solvent and repeated thrice. The maceration solution was evaporated on a rotary evaporator. The frozen filtrate was further evaporated in freeze-drying and administered in the hyperglycemia mouse model.

Table 1. Treatment group

\begin{tabular}{ll}
\hline \multicolumn{1}{c}{ Group } & \multicolumn{1}{c}{ Treatment } \\
\hline Normal (C-) & healthy mice \\
\hline Hyperglycemia (C+) & mice induced by STZ \\
\hline Treatment 1 (P1) & $\begin{array}{l}\text { mice induced by STZ and given } \\
\text { an SBME dose of 10 mg.kg } \mathrm{BW}\end{array}$ \\
\hline Treatment 2 (P2) & $\begin{array}{l}\text { mice induced by STZ and given } \\
\text { an SBME dose of 40 } \mathrm{mg}^{-1} \mathrm{~kg}^{-1} \mathrm{BW}\end{array}$ \\
\hline & $\begin{array}{l}\text { mice induced by STZ and given } \\
\text { an SBME dose of } 160 \text { mg.kg } \\
\text { Treatment 3 (P3) }\end{array}$ \\
\hline
\end{tabular}

SBME was given orally with different doses (10, 40, or $\left.160 \mathrm{mg} \cdot \mathrm{kg}^{-1} \mathrm{BW}\right)$ in hyperglycemic mice models once a day for two weeks. The female balb/c mice were divided into five different groups following the oral administration of SBME. The five groups are as follows (Table 1 ).
The design of this study was approved by the ethics commission number 1109-KEP-UB.

\section{Spleen Cells Isolation}

On the last day of treatment, mice were sacrificed, then the spleen was collected and washed in $2 \mathrm{~mL}$ PBS solution in a sterile petri dish. The spleen was crushed and homogenates were centrifugated at $1500 \mathrm{rpm}$ at $10^{\circ} \mathrm{C}$ for 5 min. The supernatant was removed and the pellet resuspended with $1 \mathrm{~mL}$ sterile PBS.

\section{Flow Cytometry Analysis}

To analyze the SBME against proinflammatory cytokines, flow cytometry analysis was performed. Flow cytometric analysis was performed by FACS CaliburTM (BD-Biosciences, San Jose, CA). Intracellular cytokine staining was performed by a Cytoperm/Cytofix kit (BDBiosciences Pharmingen) according to the manufacturer protocol and modified by Rifa'i [9]. Total of $200 \mu \mathrm{L}$ isolated cells were taken and placed on microtubes and centrifugated at 2500 rpm for 5 minutes with $4^{\circ} \mathrm{C}$ temperature. Afterward, the supernatant was separated and added with $40 \mu \mathrm{L}$ of antibody staining, then incubated for 15-20 minutes in the icebox (in the dark condition). The cells were then combined with $300 \mu \mathrm{L}$ of PBS sterile and placed into flow cytometry for analysis.

\section{Data Analysis}

The data were analyzed using one-way ANOVA with significance level $p<0.05$ using SPSS to determine the relationship between variables. It then continued with a Tukey test to find the most involving variable.

\section{RESULT AND DISCUSSION \\ SBME Inhibits IL-Ib Expression in CD4 Cells}

The administration of Bitter melon and starfruit (SBME) showed significant results. The relative number of $\mathrm{CD}^{+} \mathrm{IL}_{-}-1 \mathrm{~b}^{+}$decreased compared to hyperglycemia positive control. This study tested three groups of different doses of SBME and compared them to negative controls and hyperglycemia positive control. The result showed a decrease in inflammation of IL-1b produced by CD4 in healthy mice was $7.55 \%$. After being injected by STZ, the number of inflammations of $\mathrm{IL}-1 \mathrm{~b}$ produced by CD4 increased became $10.01 \%$ and this value is significant with healthy mice $(p<0.05)$ (Fig. 1). 

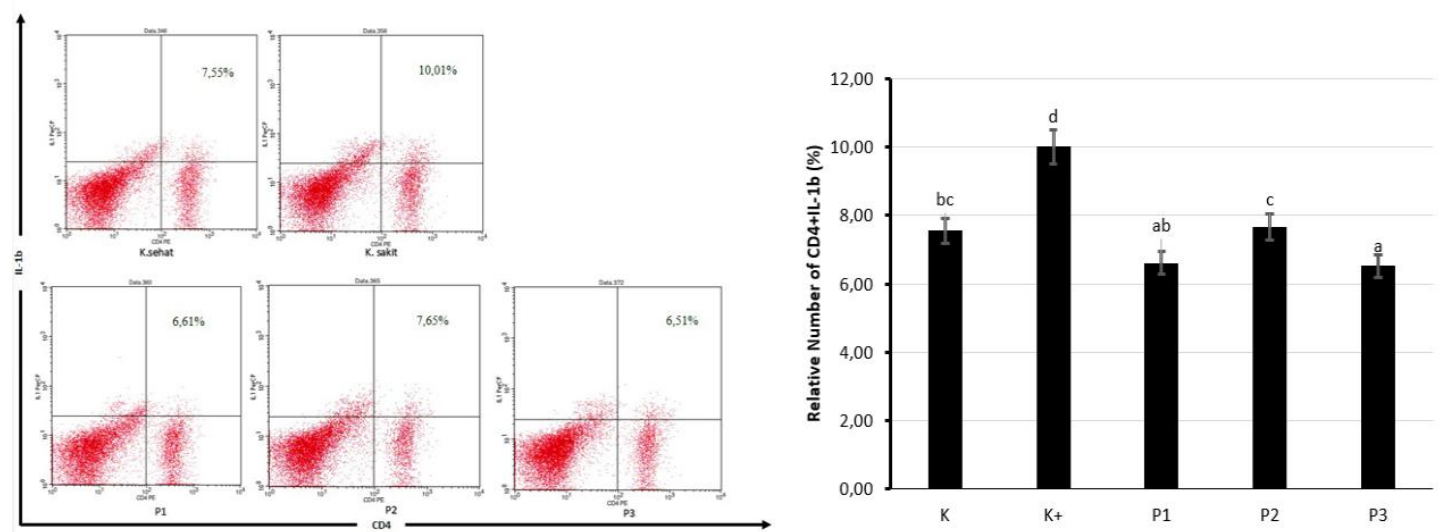

Figure 1. Production profile of IL-1b cytokine by CD4 T cells total percentage. SBME suppressed IL-1b expression in CD4 cells.

(K: a healthy group, $\mathrm{K}+$ is a positive control induced with $145 \mathrm{mg} \mathrm{kg}^{-1}$ body weight STZ, P1: treatment 1 with STZ injection and $10 \mathrm{mg} \cdot \mathrm{kg}^{-1} \mathrm{SBME}, \mathrm{P2}$ : treatment 2 with STZ injection and $40 \mathrm{mg} \cdot \mathrm{kg}^{-1} \mathrm{SBME}, \mathrm{P3}$ : treatment3 with STZ injection and $\left.160 \mathrm{mg} \cdot \mathrm{kg}^{-1} \mathrm{SBME}\right)$.

The administration of SBME in P1, P2, and P3 groups decreased the inflammation number significantly $(p<0.05)$. The result showed that the inflammation number of IL-1b produced by CD4 T cells for P1 became 6.61\%, P2 became 7.65\%, and P3 became $6.51 \%$ compared to hyperglycemic positive, which $10.01 \%$. This result showed that IL-1b produced by CD4 T cells seems important in susceptibility and progression of hyperglycemia. P3 became $6.51 \%$ compared to hyperglycemic positive, which $10.01 \%$. This result showed that IL-1b produced by CD4 T cells seems important in susceptibility and progression of hyperglycemia.

The administration of SBME in P2 with doses $40 \mathrm{mg} \cdot \mathrm{kg}^{-1}$ BW was significantly decreasing the production of IL-1b pro-inflammatory cytokine by CD4 T cells. This treatment has a more significant effect on the number of CD4 T cells that produce IL-1b compared to a dose of $10 \mathrm{mg} \cdot \mathrm{kg}^{-1} \mathrm{BW}$ and $160 \mathrm{mg} \cdot \mathrm{kg}^{-1}$ BW. SBME with specific doses can be used to reduce inflammation in patients with hyperglycemia because it can reduce the relative number of macrophage cells that produce IL-1b pro-inflammatory cytokines. IL- $1 \mathrm{~b}$ is a type of pro-inflammatory cytokine that plays a role in mediating chronic inflammation and is produced mainly by macrophages and CD4+ T cells, whose actions are mediated by the activation of kappa $B$ (NF-kB) nuclear factors [10,11,12].

SBME can reduce IL-1b production by CD4+ T cells under conditions of hyperglycemia because SBME contains a bioactive compound that beneficial to the body. SBME contains flavonoid which has anti-inflammatory activity. One of these activities is owned by a derivative of flavonoid composition consisting of isoliquiritigenin. This compound can release NF$\mathrm{kB}$ by inhibiting the release of inhibitors and inhibiting the transcription factor NFAT. It can reduce the regulation of the inflammatory response and inhibit Th17 differentiation [13]. Furthermore, the previous study also reported that flavonoids act as insulin mimetic or insulin secretagogues by influencing pleiotropic, which can prevent and overcome insulin resistance in hyperglycemic [14].

\section{SBME Inhibits IL-6 Expression in B220 Cells}

Flow cytometry analysis and statistical analysis showed that IL-6 pro-inflammatory cytokine expressing B cells (B220+IL-6+) increased in hyperglycemic mice model. The result showed that the relative number of B220+IL-6+ in hyperglycemic mice reached $8.79 \%$, while in normal mice, it was about $7.33 \%$. The relative number of IL- 6 between healthy and hyperglycemic mice showed significant result ( $p$ $<0.05$ ) (Fig. 2).

The administration of SBME against hyperglycemia on the Balb/c mice showed no significant result. The relative number of $\mathrm{B} 220+$ IL-6+ increased compared to DM positive control. This research tested three groups of different doses of SBME and compared them to negative control and hyperglycemia positive control. We found that the relative number of $\mathrm{B} 220+\mathrm{IL}-6+$ at $P 1, P 2$, and P3 difference on both decrease and increase result after given SBME orally. A significant increase observed on P3 $(p<0.05)$ compared to hyperglycemic positive control was 9.55\%. While on $\mathrm{P} 1$ and $\mathrm{P} 2$, a not significant $(P>0.05)$ increase and decrease observed and compared to the hyperglycemic positive control, was $8.44 \%$ and $8.79 \%$. (Fig. 2). 

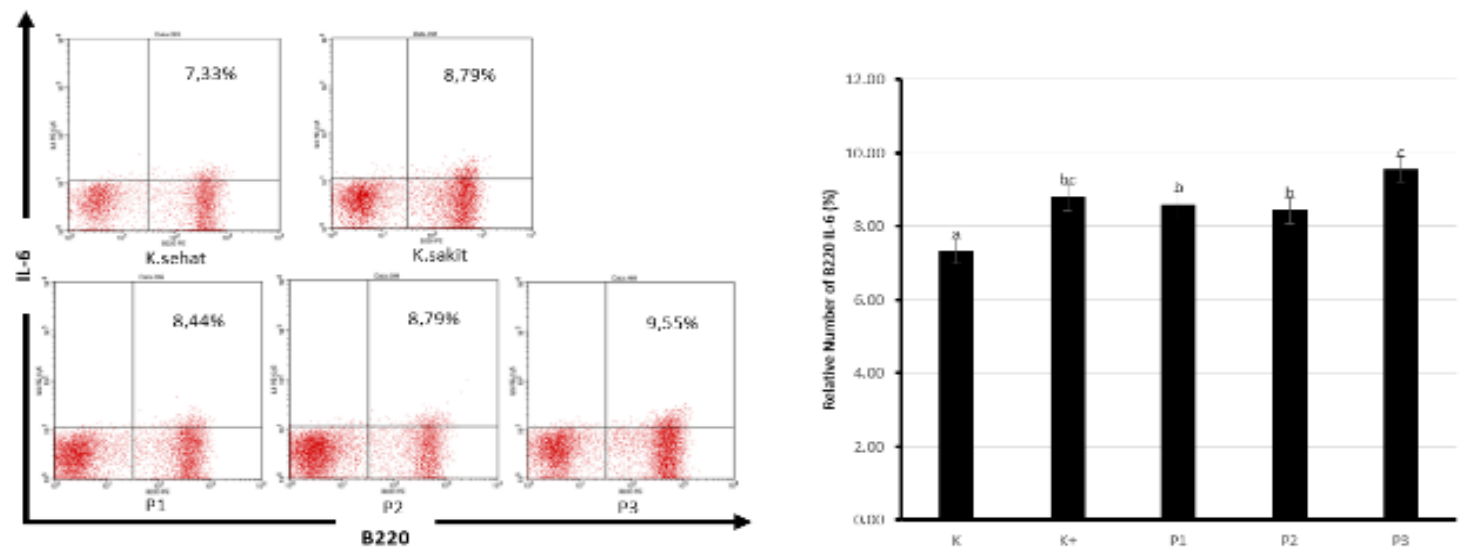

Figure 2. Production profile of IL-6 cytokine by B220 cells total percentage. (K: a healthy group, $\mathrm{K}+$ is a positive control induced with $145 \mathrm{mg} . \mathrm{kg}^{-1}$ body weight STZ, P1: treatment 1 with STZ injection and $10 \mathrm{mg} \cdot \mathrm{kg}^{-1}$ SBME, P2: treatment 2 with STZ injection and $40 \mathrm{mg} \cdot \mathrm{kg}^{-1} \mathrm{SBME}, \mathrm{P3}$ : treatment 3 with STZ injection and $\left.160 \mathrm{mg}^{\mathrm{kg}}{ }^{-1} \mathrm{SBME}\right)$.

Based on the result shown by flow cytometry analysis, the conclusion is, SBME did not give a specific result to reduce the relative number of B220+ IL-6+. The administration of SBME at a dose of $10 \mathrm{mg} \cdot \mathrm{kg}^{-1} \mathrm{BW}, 40 \mathrm{mg} \cdot \mathrm{kg}^{-1} \mathrm{BW}$, and 160 $\mathrm{mg} . \mathrm{kg}^{-1} \mathrm{BW}$ has not been able to reduce the number of IL- 6 cytokines explored by lymphocyte $B$ cells. The dosage also provides the amount of IL-6 pro-inflammatory cytokines. The given SBME cannot be used to reduce inflammation in patients with hyperglycemia.

Increased IL-6 cytokine production by B220 lymphocyte cells was due to an increase in $B$ lymphocyte cell activity in producing IL-6 cytokines, which increases the increase in hyperglycemia, which can cause inflammation [15]. Besides, increasing the relative number of B220 cells in hyperglycemia mice injected with STZ will form free radicals in the body that cause oxidative reactions in various organs of the body and cause inflammation. The resulting inflammation will activate activation of the transcription factor Nf-kB, which is a transcription factor that increases the production of inflammatory cytokines and results in the proliferation and differentiation of CD40 cells (B220) through the application of cytokine regulations [16].

The increase in the relative number of IL- 6 cells by $B 220$ cells during SBME processing is due to the activation of the trans-signaling pathway to produce IL-6 pro-inflammatory cytokines [17]. Besides, the composition of flavonoids and momordicine in SBME also has an important role. Mammon compounds can help activate and activate B cell proliferation. Flavonoid compounds can also act as Mitogen-Activated Protein Kinase (MAPK), which can fight $B$ cell proliferation [18]. This MAPK activation can help the phosphorylation of transcription factor proteins such as Nf-KB and activating it as a transcription [16], thus increasing the inflammatory effect. So, based on the results of this study, it can be known about the content of SBME compounds, which are immune stimulants, which can trigger the activation of Nf-kB thus increasing pro-inflammatory cytokines in hyperglycemia.

\section{CONCLUSION}

In this study, Bitter melon combined with star fruit (SBME) gave varying results as an antiinflammatory depending on the therapeutic dose. This result happened because the dose used reduces the production of IL-1b cytokines, not with IL-6 cytokines. Thus because the dose used here was low. SBME can be only used to cure inflammation in hyperglycemia, but with further research doses. SBME activity with the right dose was able to reduce the relative number of pro-inflammatory cytokines such as IL1B and IL-6 produced by T lymphocytes or B lymphocytes.

\section{REFERENCES}

[1] Yan, L.J. 2014. Pathogenesis of chronic hyperglycemia: from reductive stress to oxidative stress. J. Diabetes Res. 137919. 111.

[2] Fernandez-Rene J., M. Vayreda, C. Richart, C. Gutierrez, M. Broch, J. Vendrell, W. Ricart. 2001. Circulating interleukin-6 levels, blood pressure and insulin resistance in apparently healthy man and women. J. Clin. Endocrinol. Metab. 86. 1154-1159.

[3] Lorenzo. O., B. Picatoste, S. Ares-Carrasco, E. Ramírez, J. Egido, J. Tuñón. 2011. 
Potential role of nuclear factor $\mathrm{KB}$ in diabetic cardiomyopathy. Mediators Inflamm. 1-9.

[4] Khairunnisa, E.N., H.S. Sastramihardja, S. Bhekti. 2014. Efek infusa belimbing wuluh (Averrhoa bilimbi) dalam menurunkan kadar glukosa darah puasa dan 2 jam post prandial mencit model diabet. Prosiding Pendidikan Dokter. 358-364.

[5] Nagy, M., M.A. Bastawy, N. Abdel-Hamid 2012. Effects of Momordica charantia on streptozotocin-induced diabetes in rats: role of insulin, oxidative stress and nitric oxide'. Int. J. Health Sci. 2(2). 8-13.

[6] Joseph, B., D. Jini. 2013. Antidiabetic effects of Momordica charantia (bitter melon) and its medicinal potency'. Asian Pac. J. Trop. Dis. 3(2). 93-102.

[7] Hidayati, D., A. Faizah, E.N. Prasetyo, N. Jadid, N. Abdulgani. 2018. Antioxidant capacity of snakehead fish extract (Channa striata) at different shelf life and temperatures. IOP Conference Series: Journal of Physics: Conference Series 1028. DOI: 10.1088/17426596/1028/1/012021.

[8] Susanti, E.Y., A. Candra, C. Nissa. 2017. Pengaruh pemberian sari belimbing wuluh (Averrhoa bilimbi. L) terhadap kadar glukosa darah puasa wanita dewasa. Journal of Nutrition and Health. 5(2). 102115.

[9] Rifa'i, M., N. Widodo. 2014. Significance of propolis administration for homeostasis of CD4+CD25+ T immunoregulatory cells controlling hyperglycemia. Springer Plus. 3. 526.

[10] Numasaki, M., J. Fukushi, M. Ono, S.K. Narula, P.J. Zavodny, T. Kudo, ... M.T. Lotze. 2003. Interleukin-17 promotes angiogenesis and tumor growth. Blood. 101(7). 26202627.

[11] Liang, Y., Y. Zhou, P. Shen. 2004. NF-kB and its regulation on the immune system. Chinese Society of Immunology. 1(5). 343350.

[12] Tak, P.P., G.S. Firestein. 2014. NF-kB: A key role in inflammatory diseases. J. Clin. Invest. 107(1). 7-11.

[13] Martinez, G., M.R. Mijares, J.B De Sanctis. 2019. Effect of flavonoids and its derivatives on immune cell responses. Recent Pat. Inflamm. Allergy Drug Disc. 13(2). 84-104

[14] Gupta, R., M. Mathur, V.K. Bajaj, P. Katariya, S. Yadav, R. Kamal, R.S. Gupta. 2011. Evaluation of the antidiabetic and antioxidant activity of Moringa oleifera in experimental diabetes. J. Diabetes. 4. 164171.

[15] Defuria, J., A.C. Belkina, M.J. Bogdan, J.S. Cappione, J.D. Carr, Y.R. Nersesova, D. Markham, K.J. Strissel, A.A., B.S. Nikolajczyk. 2013. B cells promote inflammation in obesity and type 2 diabetes through regulation of T-cell function and an inflammatory cytokine profile. Prot. Natl. Acad Sci. USA. 110(13). 5133-5138

[16] Craxton, A., G. Shu, J.D. Graves, J. Saklatvala, E.G. Krebs, E.A. Clark. 1998. P38 MAPK is required for CD-4induced gene expression and proliferation in $B$ lymphocyte. J. Immunol. 161. 3225-3230.

[17] Scheller, J., A. Chalaris, D. Schmidt-Arras, S. Rose-John. 2013. The Pro- and AntiInflammatory Properties of the Cytokine Interleukin-6. Biochimicaet Biophysica Acta.1 81(5). 878-888.

[18] Middleton, E.Jr., C. Kandaswami, T.C. Theoharides. 2000. The effects of plant flavonoids on mammalian cells: implications for inflammation, heart disease, and cancer. J. Pharmacol. 52(4). 673-751. 